\title{
IMPACT OF GENETICALLY MODIFIED STACKED MAIZE NK603 × MON810 ON THE GENETIC DIVERSITY OF RHIZOBACTERIAL COMMUNITIES
}

\author{
KATARÍNA ONDREIČKOVÁ ${ }^{1 *}$, JÁN KRAIC ${ }^{1,2}$ \\ ${ }^{1}$ National Agricultural and Food Centre - Research Institute of Plant Production Piešt'any, Slovak Republic \\ ${ }^{2}$ University of SS. Cyril and Methodius in Trnava, Slovak Republic
}

ONDREIČKOVÁ, K. - KRAIC, J.: Impact of genetically modified stacked maize NK603 $\times$ MON810 on the genetic diversity of rhizobacterial communities. Agriculture (Polnohospodárstvo), vol. 61, 2015, no. 4, pp. 139-148.

Field trials with the genetic modified (GM) maize stacked
hybrid NK603 $\times$ MON810 performed in two different
locations in the Czech Republic were used for evaluation
of genetic diversity of rhizosphere bacterial communities
using the terminal restriction fragment length polymor-
phism. Statistically significant differences in the number
of terminal restriction fragments (i.e. bacterial richness)
between GM and non-GM maize were not detected. Di-
versity indices (Gini-Simpson and Shannon's) revealed Key words: bacterial community, genetically modified maize, NK603 $\times$ MON810, rhizosphere, stacked hybrid, T-RFLP

Commercial cultivation of genetically modified (GM) plants officially began in the year 1996. The most important producers of foods and feeds over the world (USA, Canada, Argentina, Brazil, India, China, and Australia) have adopted GM crops since that time as equivalents of conventional, non-GM crops. However, cultivation of GM crops in Europe is still rigidly regulated and limited to only negligible growing area in several countries. Nevertheless, the field trials of GM crops with different genetic modification events are performing every year in many European countries, including the Czech Republic. Parameters evaluated in the phase of authorization of GM plants for cultivation include also possible, adverse, and unintended impacts of their growing on different components of environment. higher bacterial diversity in non-GM sample from location Ivanovice na Hané and in the GM maize from location Probluz, but statistical significant differences between GM and non-GM samples were not detected. Additionally, using principal component analysis and cluster analysis, no substantial variation in the composition of bacterial communities between GM and conventional maize were observed but the differences among individual collection sites were recorded.
The maize hybrid NK603 $\times$ MON810 is stacked $F_{1}$ hybrid developed by classical hybridization of the herbicide-tolerant maize inbred NK603 (OECD identifier: MON-ØØ6Ø3-6) with the insect-resistant maize inbred MON810 (MON-ØØ81Ø-6). The hybrid NK603 $\times$ MON810 was approved for food and feed production for the first time in the year 2004 (http://cera-gmc.org/GmCropDatabaseEvent/ NK603\%20x\%20MON810). Plants of stacked hybrid NK603 $\times$ MON810 express two novel proteins. The protein CP4 EPSPS confers tolerance to the glyphosate, the active ingredient of several herbicides. The protein Cry $1 \mathrm{Ab}$ (belonging to the group of delta-endotoxins) is responsible for resistance to the European corn borer (Ostrinia nubilalis) and other lepidopterans. These proteins are products of genes cp4 epsps and crylAb obtained from parental maize

Mgr. Katarína Ondreičková, PhD. (*Corresponding author), prof. RNDr. Ján Kraic, PhD., National Agricultural and Food Centre - Research Institute of Plant Production, Bratislavská cesta 122, 92168 Piešt'any, Slovak Republic. E-mail: ondreickova@vurv.sk

prof. RNDr. Ján Kraic, PhD., University of SS. Cyril and Methodius in Trnava, Nám. J. Herdu 2, 91701 Trnava, Slovak Republic. E-mail: jan.kraic@ucm.sk 
genotypes. However, original donors of both genes are soil bacteria Agrobacterium tumefaciens and Bacillus thuringiensis, respectively. The Cry1 Ab protein has not enzymatic activity and does not affect the plant metabolism, the protein CP4 EPSPS participates in the shikimate metabolic pathway.

Generally, plants interact with environment and can affect also the soil microorganisms, especially those living in the rhizosphere. Very intensively by released root exudates, even more in genetically modified plants where introduced transgene(s) might modify this impact by changes in rhizodeposition (Kowalchuk et al. 2003). Roots of the GM plants producing the Cry1 $\mathrm{Ab}$ protein (named also Bt-toxin) release this protein into the soil by exudation, the protein is able to accumulate in soil by adsorption and binding to surface-active particles and can keep insecticidal activity for at least 180 days (Saxena et al. 2002). Exudation of substances by roots into the soil is standard phenomenon also in the glyphosate-tolerant GM plants. Nevertheless, more typical and significant in this type of GM plants is translocation of glyphosate from foliar tissues to roots after treatment by glyphosate-based herbicides and its exudation along with soluble carbohydrates and amino acids into the soil (Coupland $\&$ Caseley 1979). Although lower aggressiveness of glyphosate for soil bacterial communities in comparison with other herbicides, especially tank mixes has been detected by Valverde et al. (2014) using the glyphosate-tolerant Bt-maize. Also Barriuso et al. (2011) concluded that the glyphosate treatment during cultivation did not seem to significantly change the maize rhizobacterial communities when compared to those of the untreated soil.

The structure and diversity of rhizobacterial community is an important parameter of soil quality and functionality. Well balanced rhizosphere constitution is able to stimulate plant growth, mediate adaptation of plant against environmental stresses, improve resistance against pathogens, as well as increase yield (De-Bashan et al. 2012). Nevertheless, communities of soil microorganism, particularly those living in the rhizosphere, are sensitive to soil properties and their changes. Such changes can be induced also by pesticides and herbicides either applied directly or mediated by root exudation.

Methods based on analysis of metagenomic DNA isolated from the soil are very effective for different studies of microorganisms living in soil and interacting with plants, biotic, and abiotic factors. An effective technique for study of bacterial metagenomic DNA using small subunit ribosomal DNA sequences (Avaniss-Aghajani et al. 1994) was later named as terminal restriction fragment length polymorphism (T-RFLP) (Liu et al. 1997).

The aim of this study was to compare genetic variation and differences between bacterial communities in the rhizosphere of genetically modified maize stacked hybrid NK603 $\times$ MON810 and nonGM maize using the T-RFLP.
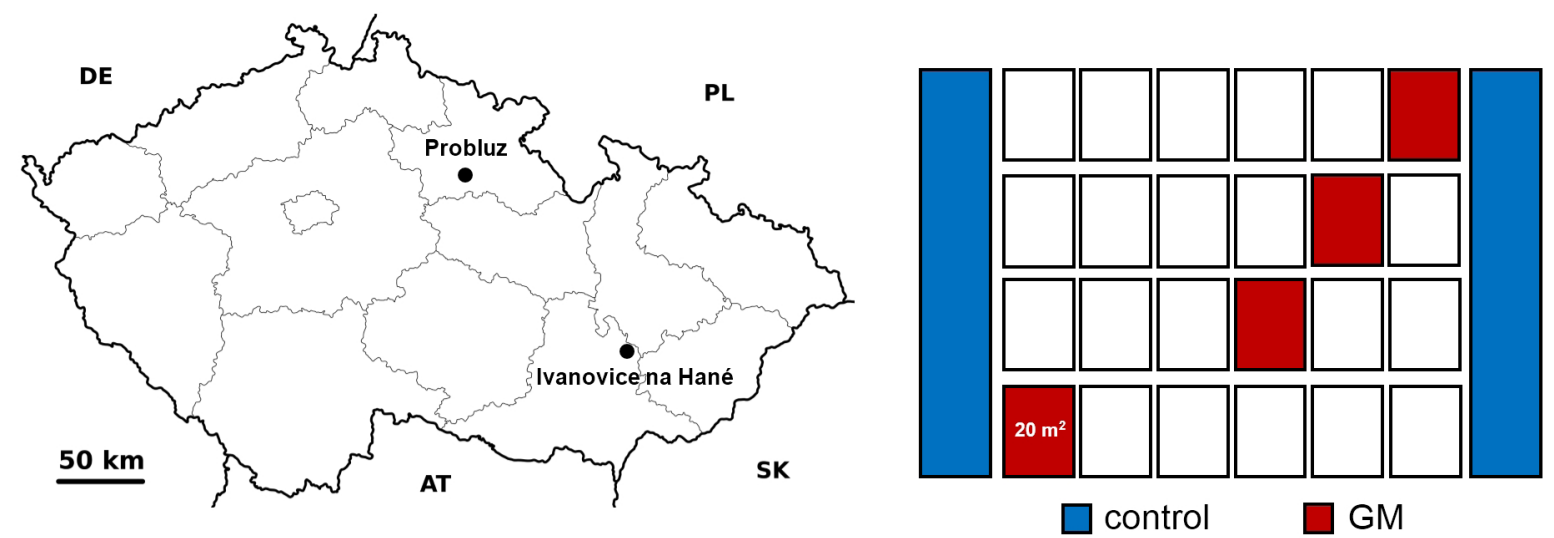

Figure 1. Two locations (black point) of field trials with GM maize hybrid NK603 $\times$ MON810 in the Czech Republic (left). Sampling sites of rhizosphere samples from NK603 × MON810 and non-GM plants. White coloured plots represent GM maize with different treatments in comparison with control (right) 


\section{MATERIAL AND METHODS}

\section{Field trials}

The genetically modified maize hybrid NK603 $\times$ MON 810 was tested in two experimental locations in the Czech Republic - Ivanovice na Hané and Probluz (Crop Research Institute, Prague, Czech Republic, Figure 1, left). These locations differ in many characteristics. Characteristics of the location Ivanovice na Hané are: altitude 225 meters about sea level, the soil type is degraded chernozem, soil-forming substrate is loess, mainly alluvial and diluvial loamy soil on loess substrates, topsoil is dark brown clay with content of humus $4.39 \%$, reaching an average depth of about $40 \mathrm{~cm}$, average temperatures (during 20 years) $9.2^{\circ} \mathrm{C}$, the annual average precipitation $548 \mathrm{~mm}$. Characteristics of the location Probluz are: altitude 265 meters above sea level, soil type is illimerized brown soil on loess, the topsoil with content of humus $2.34 \%$ with the average depth $30-40 \mathrm{~cm}$, average temperatures (during 20 years) $8.1^{\circ} \mathrm{C}$, the annual average precipitation is $597 \mathrm{~mm}$. The pesticide treatments on the experimental plots were realized using Roundup Rapid (glyphosate) in concentration of $2.4 \mathrm{l} / \mathrm{ha}$.

\section{Sampling of rhizosphere}

Samples were collected from the rhizosphere of mature GM maize hybrid NK603 × MON810 (4 independent samples) and from the control non-GM maize (2 independent samples) in October 2012 (Oct 9, 2012 in Ivanovice na Hané, Oct 10, 2012 in Probluz). The exact daily precipitation and temperature were measured at 10-day interval before collection of rhizosphere samples (Figure 2). The rhizosphere samples were collected from separate plot in experimental field (Figure 1, right) and three different sites were selected in each plot. Plants were taken out from soil, residues of soil were gently removed from roots and the rhizosphere soil was scraped from roots with sterile scalpel, subsequently cooled and stored before analysis at $4^{\circ} \mathrm{C}$.

\section{Extraction of metagenomic DNA and T-RFLP analy-} sis

Each rhizosphere sample was homogenized and metagenomic DNA was extracted by the PowerSoil DNA Isolation Kit (MoBio Laboratories Inc., Carlsbad, USA). Quantity and quality of isolated DNA was detected spectrophotometrically (Nanodrop 1000 Spectrophotometer, Thermo Fisher Scientific Inc., Wilmington, USA) and samples were diluted to the same final concentration $20 \mathrm{ng} / \mu 1$.

The partial 16S rRNA gene sequences were amplified using the eubacterial universal primers 8F (Edwards et al. 1989) and 926R (Muyzer et al. 1995). The forward primer $8 \mathrm{~F}$ was labelled at the 5 '-end with the 6-FAM fluorescent dye. DNA amplifications were carried out in $50 \mu 1$ reaction mixtures containing FailSafe ${ }^{\mathrm{TM}}$ PCR PreMix Selection

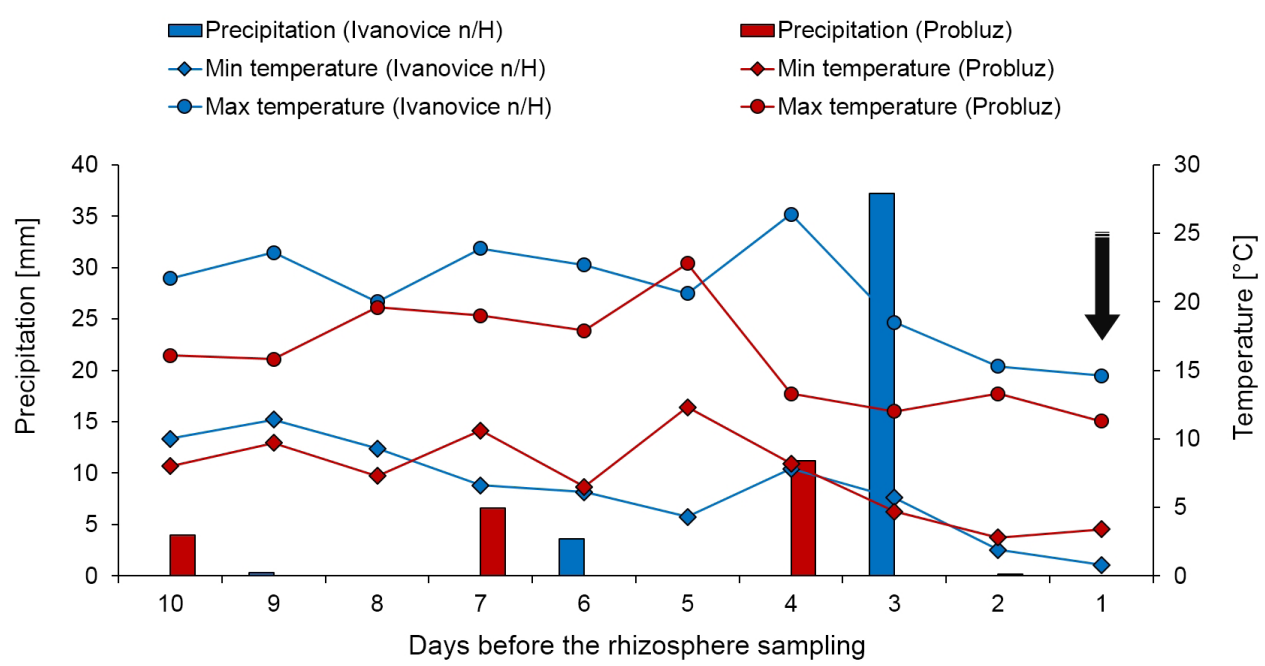

Figure 2. Precipitation and temperature in the field trial locations 10 days before sampling both locations. The black arrow indicates the sampling day 
Kit (Epicentre Biotechnologies, Madison, USA), $0.10 \mu \mathrm{M}$ of both primers and $1 \mu 1$ of DNA. PCR conditions were as follows: initial denaturation at $95^{\circ} \mathrm{C}$ for $2 \mathrm{~min}, 35$ cycles of denaturation at $94^{\circ} \mathrm{C}$ for $30 \mathrm{~s}$, annealing at $47^{\circ} \mathrm{C}$ for $30 \mathrm{~s}$ and elongation at $72^{\circ} \mathrm{C}$ for $1 \mathrm{~min}$, and final elongation at $72^{\circ} \mathrm{C}$ for 10 min using the GeneAmp PCR System 9700 (Applied Biosystems, Thermo Fisher Scientific Inc., Wilmington, USA). Triplicate reactions were pooled, and PCR products were purified by the PCR Purification \& Agarose Gel Extraction Combo Kit (Thermo Fisher Scientific Inc., Wilmington, USA). Purified PCR products were digested with $C f_{o} \mathrm{I}$ restriction endonuclease (Promega Corp., Madison, USA) in digestion mixture containing $10 \mathrm{U}$ of restriction enzyme, $1 \times$ buffer $\mathrm{B}, 0.1 \mathrm{mg} / \mathrm{ml}$ of Bovine serum albumin, and $10 \mu 1$ of purified PCR products. The mixture was incubated for $3 \mathrm{~h}$ at $37^{\circ} \mathrm{C}$. Samples were then purified using a purification kit and dissolved in sterile water. One microliter of purified products was added to $9 \mu \mathrm{l}$ of formamide containing LIZ1200 size standard (Applied Biosystems, Thermo Fisher Scientific Inc., Wilmington, USA), denatured at $95^{\circ} \mathrm{C}$ for $3 \mathrm{~min}$, and separated by capillary electrophoresis using the ABI 3100 Prism Avant (Applied Biosystems, Thermo Fisher Scientific Inc., Wilmington, USA) and analysed by the Peak Scanner 2 (Applied Biosystems, Thermo Fisher Scientific Inc., Wilmington, USA). Only fragments in range 69-914 bp were used for evaluation with minimum peak height threshold of 50 fluorescence units.

\section{Statistical analyses}

Statistically significant differences among samples were tested using the Fisher's least significant difference $(L S D)$ procedure at the $95.0 \%$ confidence level. The presence/absence of specific T-RFs was used for comparison of community similarity between GM and control samples. T-RF peaks were classified as present (1) or absent (0) in each sample, and the binary system was used for principal component analysis (PCA) using the scores of the first three principal components and to create dendrograms using the Ward's clustering and squared Euclidean distance measure. All statistical analyses were performed using the software Statgraphics X64 (Statpoint Technologies, Inc., Warrenton, USA). Diversity indices were calculated from standardized profiles of individual soil samples using the number and height of peaks in each profile as representations of the number and relative abundance of phylotypes. The Gini-Simpson index (Jost 2006) was calculated as follows:

$$
1-\lambda=\sum\left(\rho_{\mathrm{i}}^{2}\right)
$$

where $\lambda$ is Simpson diversity index and $p$ is the proportion of an individual peak height relative to the sum of all peak heights. The Gini-Simpson index measures the probability that two sampled individuals belong to different species. The Shannon's diversity index (Shannon \& Waever 1948) was calculated as follows:

$$
H^{\prime}=-\sum\left(\rho_{\mathrm{i}}\right)\left(\ln \rho_{\mathrm{i}}\right)
$$

and this index is commonly used to characterize species diversity in a community. The Shannon's diversity index indicates not only the number of species but how the abundance of the species is distributed among all the species in the community. Pielou evenness index (Pielou 1966) was derived from Shannon's diversity index and was calculated as follows:

$$
J^{\prime}=H^{\prime} / H^{\prime}{ }_{\text {max }}
$$

where $H_{\text {max }}^{\prime}=\ln (S)$ where $S$ represents the total number of species. The values are between 0 and 1 and the closer it is to 1 the more equally individuals are distributed.

\section{RESULTS AND DISCUSSION}

\section{Microbial biomass and bacterial genetic diversity}

Samples of rhizosphere were collected from four plots sown with stacked hybrid NK603 $\times$ MON810 and from two plots sown with conventional nonGM maize in two locations. Total microbial biomass represented by metagenomic DNA isolated from the rhizosphere was higher in non-GM than in GM samples from both locations (Figure 3a), nevertheless statistically significant differences between non-GM and GM maize were not detected ( $L S D, \alpha=0.05)$.

The number of T-RFs detected in non-GM samples was in range 55-60 and in GM samples 10-51 with total of 93 different T-RFs collected in Ivanovice na Hané. The bacterial richness in GM samples decreased by $52.6 \%$ in comparison with non-GM. 
The number of T-RFs in location Probluz detected in non-GM samples was in range 9-32 and in GM samples 13-36 with total of 54 different T-RFs. In this case, bacterial richness in GM samples increased by $13.5 \%$ in comparison to non-GM samples. Statistically significant differences between $\mathrm{GM}$ and non-GM samples in both locations were not detected ( $L S D, \alpha=0.05$; Figure $3 b$ ). Diversity indices, such as the Gini-Simpson index and Shannon's diversity index, had higher average value in non-GM samples from Ivanovice na Hané but on the other hand in GM samples from Probluz (Figure 3c, d). The Pielou evenness index for both locations had higher average value in GM samples than in nonGM (Figure 3e). Although in some cases the differ- ences between the GM and non-GM control samples were more pronounced, statistical significant differences between them were not detected in any case ( $L S D, \alpha=0.05$ ). Similar results about the Shannon's index and evenness were published by Prischl et al. (2012). They studied root-associated endophyte communities in the rhizosphere of three GM and four conventional maize and statistical differences among any of seven maize cultivars were not detected. Also Lupwayi and Blackshaw (2013) have not detected the impact of Bt-crops (corn and canola), insecticide application, and crop rotation on the soil microbial biomass and diversity in four from five tested years. On the other hand, Blackwood et al. (2007) presented that diversity indices provide a)

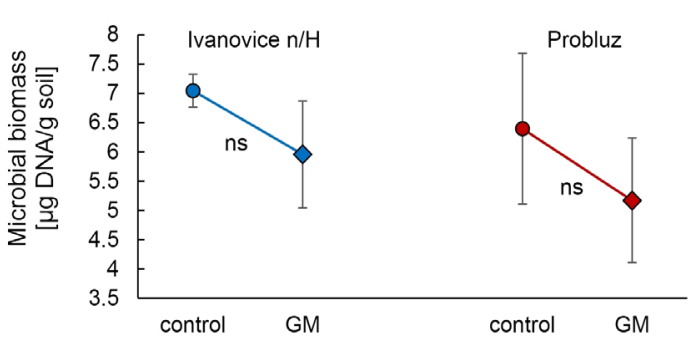

c)

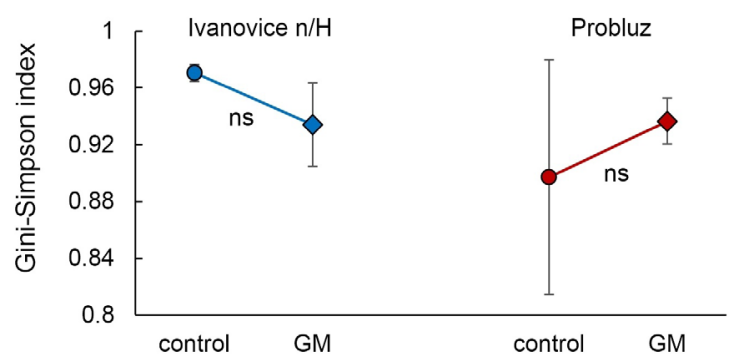

e)

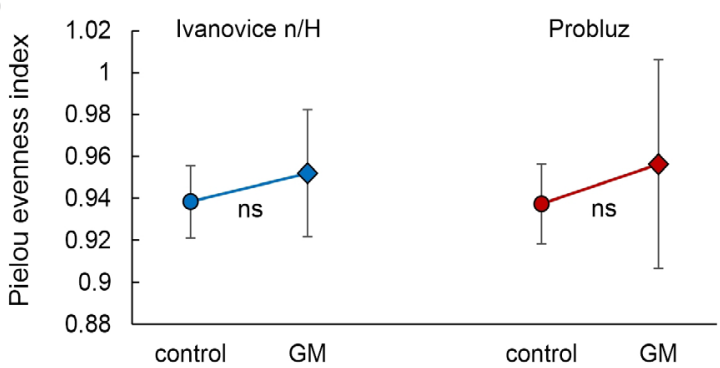

b)

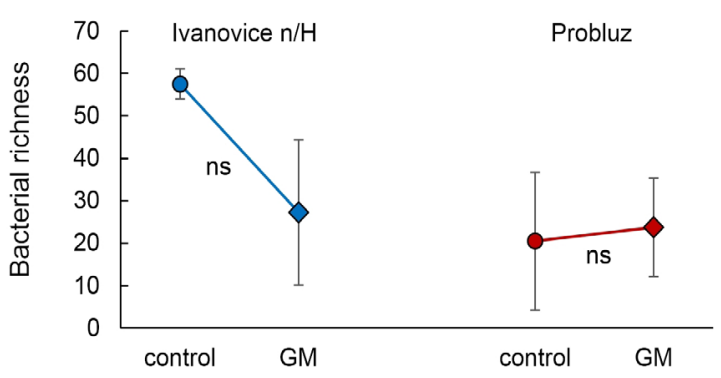

d)

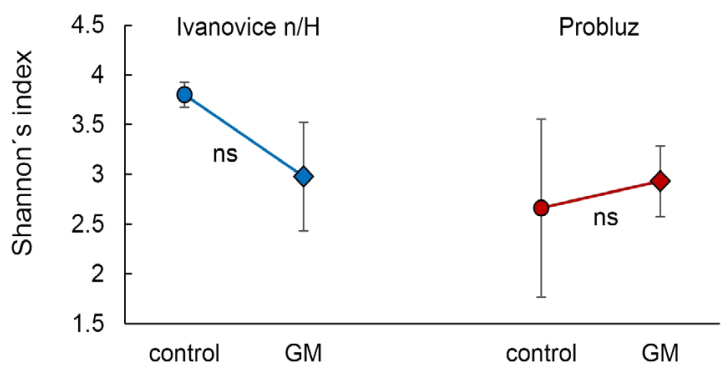

Figure 3. The total microbial biomass detected as the metagenomic DNA extracted from the rhizosphere (a); bacterial richness (number of T-RFs) (b); Gini-Simpson index (c); Shannon's index (d); Pielou evenness index (e); (ns - not significant, $L S D, \alpha=0.05$ ) 
inaccurate insights into the actual diversity of bacterial communities and other multivariate methods should be used.

The composition of rhizosphere bacterial community

The impact of gene stacked event in maize on the rhizosphere bacterial community composition was evaluated using the Principal component analysis (PCA) with three main principal component used. As described above, this or other multivariate methods are more convenient than diversity indices due to higher sensitivity (Blackwood et al. 2007). Based on the PCA analysis, two samples from rhizosphere of GM maize collected in Ivanovice na Hané were separated by the first principal component from the others (left side of the PCA graph in Figure 4a). The non-GM samples were grouped with two remaining GM samples together and this suggests that different bacterial composition among them was not detected (Figure 4a). Three main principal components

a)

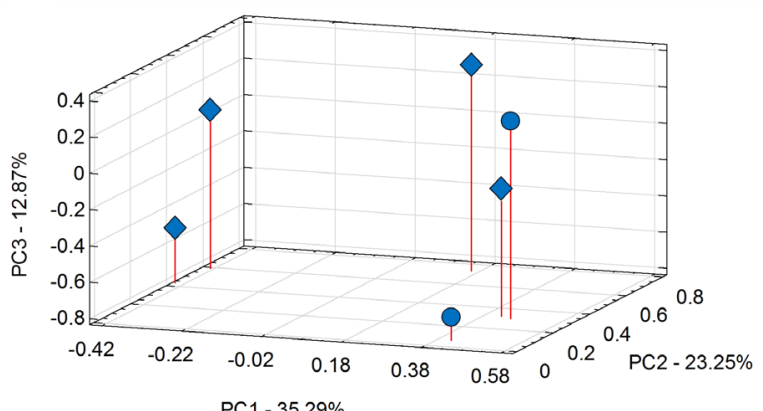

revealed lower degree of variation of rhizosphere samples collected in Probluz than in Ivanovice na Hané (Figure 4b). Samples from Probluz were divided by the second principal component, not by the first, in contrast to the samples from previous location. In this case, samples were more or less evenly spaced apart, with no sign of grouping of GM or control samples (Figure 4b).

When the T-RFLP data from both locations were grouped into a single statistical file, samples were separated by locations, not by genetic modification. Samples collected in Ivanovice na Hané were divided by the third principal component from samples collected in Probluz. This sample distribution is seen in 3-D PCA graph (Figure 5a) and not in frequently used 2-D graph (data not shown). In 2-D view, samples were distributed regardless of the genetic modification or site collection. This observation from the 3-D PCA analysis (Figure 5a) was also partially supported by the cluster analysis (Figure 5b). Two main clusters A and B were formed, while

b)

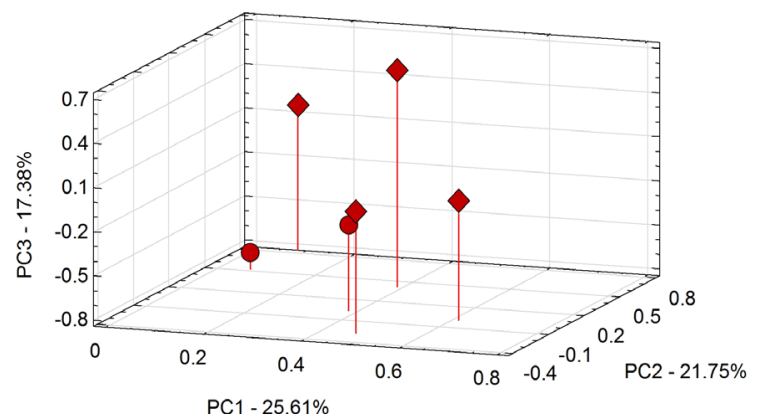

Figure 4. PCA analysis of T-RFLP data collected in Ivanovice na Hané (a) and Probluz (b); circle - non-GM samples, diamond - GM samples. PCA graphs explained total of $71.41 \%$ and $64.74 \%$ (respectively) of the variability in the data

a)

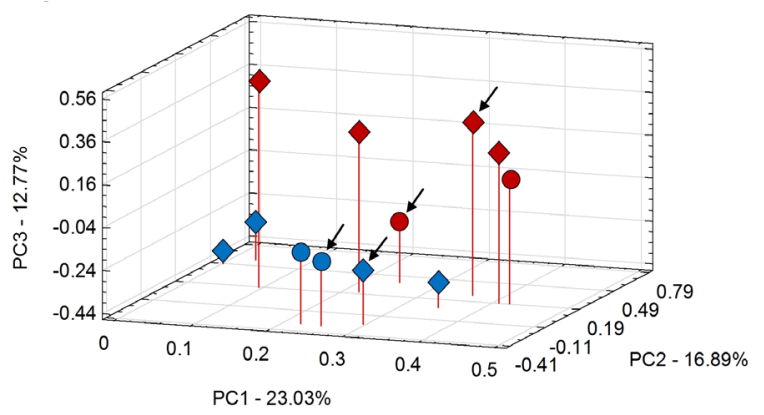

b)

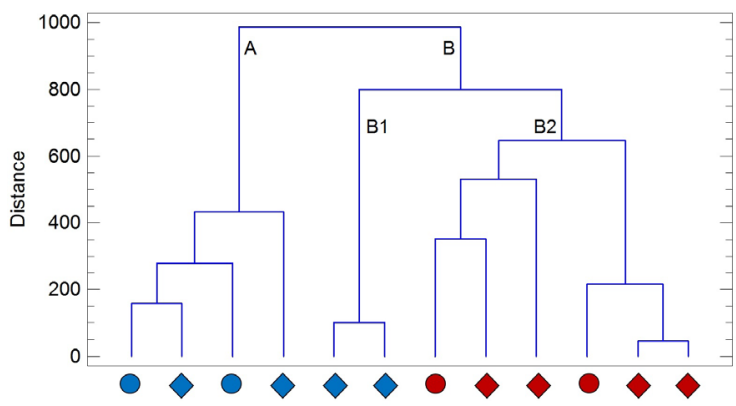

Figure 5. The PCA analysis (a) and cluster analysis (b) from the T-RFLP data of rhizosphere samples collected in two locations; circle - non-GM samples, diamond - GM samples, blue color - Ivanovice na Hané, red color - Probluz; the black arrows indicate samples, whose T-RFLP profiles were used in Figure 6 
the cluster A were made up with 4 samples from Ivanovice na Hané and cluster B with remaining samples. Based on the cluster analysis two rhizosphere samples from GM maize collected in Ivanovice na Hané had more similar bacterial community composition with all samples collected in Probluz and formed a separate B1 subcluster (Figure $5 b$ ). The composition of bacterial communities from non-GM samples was not more different from GM samples than from themselves. Even the non-GM samples in dendrogram were placed together with GM samples at the lowest level of clustering as seen in Figure $5 \mathrm{~b}$.

In our case the observed differences in the composition of rhizobacterial communities between two locations were probably caused mainly by different soil type and by the weather conditions in the given locality. These factors likely caused elimination or reduction of the growth of certain bacterial groups (Figure 6). The missing bacterial species in T-RFLP profiles from samples collected in Probluz were apparently present in very small amounts but their presence was below the detection limit of T-RFLP analysis. This statement is supported by the fact that in T-RFLP profiles from samples collected in Probluz very small peaks were recorded in the areas of their presence in Ivanovice na Hané (Figure 6, shown by the open arrows). A similar result has been published by Fang et al. (2007) using the denaturing gradient gel electrophoresis when tested the impact of $\mathrm{Bt}$ and non-Bt corn residues on soil microbial communities. They observed that a number of low-intensity bands varied across the different collection dates and these undetected weak bands were occurred in all sampling dates but they were below the limits of density values.

Generally, the different types of tillage have a fundamental and long lasting impact on soil microbial communities (Buckley \& Schmidt 2001; Clegg et al. 2003). The various abiotic (season, meteorological conditions, locality, soil type, and other) and biotic factors (plant growth stage, plant genotype, and others) are more substantial drivers of changes in the rhizosphere microbial community composition than possible effect of GM plant (Heu-

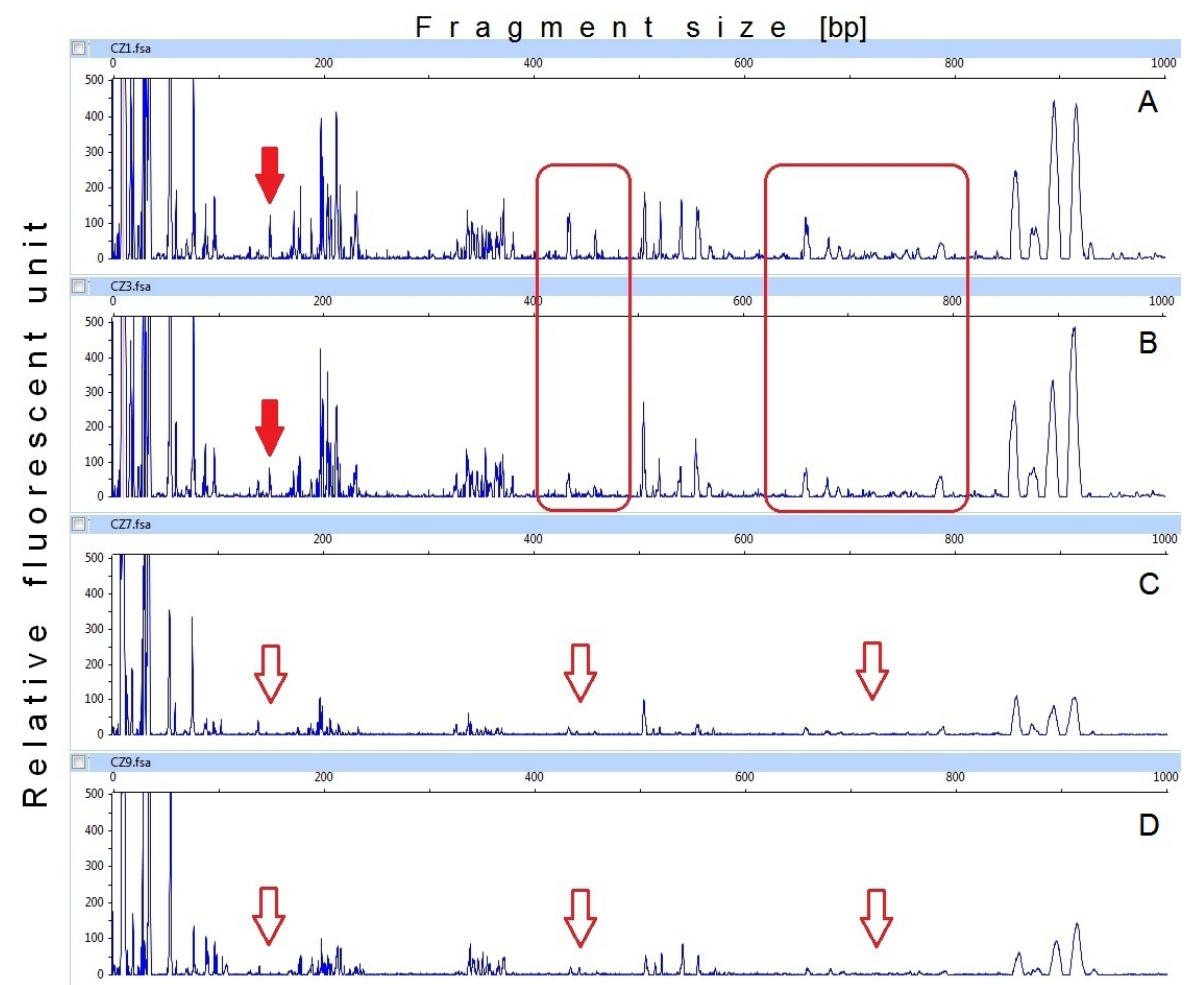

Figure 6. The T-RFLP profiles of four rhizosphere samples; A - non-GM sample Ivanovice na Hané, B - GM sample Ivanovice na Hané, C - non-GM sample Probluz, D - GM sample Probluz. The frame and fill arrow in the first two T-RFLP profiles acquired from Ivanovice na Hané denote bacterial groups not present in samples collected in Probluz, as indicated by open arrows. 
er \& Smalla 1999; Griffiths et al. 2000; Lukow et al. 2000; Dunfield \& Germida 2001; Gyamfi et al. 2002; Heuer et al. 2002; Houlden et al. 2008; Berg \& Smalla 2009; Li et al. 2014, Ondreičková et al. 2014). It is important that all these factors should be taken into account when assessing the impact of GM plants on soil microbial diversity, because these abiotic and biotic factors represent the "natural source" of microbial variation in the rhizosphere (Kowalchuk et al. 2003). The expression of the cry transgenes did not change bacterial endophyte communities (Prischl et al. 2012), bacterial communities in the rhizosphere (Devare et al. 2004; Brusetti et al. 2005; Icoz \& Stotzky 2008), or soil microbial communities (Fang et al. 2007; Song et al. 2014). The minor changes of microbial community composition between GM and non-GM maize was published by Blackwood and Buyer (2004) and Griffiths et al. (2006) but these differences were lower than differences caused by common biotic and abiotic factors.

\section{CONCLUSIONS}

Genetically modified crops are worldwide cultivated almost two decades and the possible risks of their cultivation for environment are analysed. Many studies have already been performed to identify potential risks in different locations and conditions. An impact of GM stacked hybrid maize NK603 $\times$ MON810 on the rhizosphere bacterial communities in two locations of the Czech Republic have been studied. The impact of the GM maize expressing the cp 4 epsps and crylAb transgenes on the changes in the bacterial genetic diversity was not detected. Differences in the composition of rhizosphere bacterial communities were detected as the result of sampling site due to the various soil type and weather conditions.

Acknowledgements. This study was supported by the project no. ITMS 26210120039 "Systems biology for protection, reproduction and use of plant resources of Slovakia" founded by the Operational Program Research and Development co-financed from the European Union Fund for Regional Development and by OP Research and Development: Development of new types of ge- netically modified plants with farm traits (ITMS 26220220189), by the European Regional Development Fund.

\section{REFERENCES}

AVANISS-AGHAJANI, E. - JONES, K. - CHAPMAN, D. - BRUNK, C. 1994. A molecular technique for identification of bacteria using small subunit ribosomal RNA sequences. In BioTechniques, vol. 17, pp. 144-149.

BARRIUSO, J. - MARÍN, S. - MELLADO, R.P. 2011. Potential accumulative effect of the herbicide glyphosate on glyphosate-tolerant maize rhizobacterial communities over a three-year cultivation period. In PLoS ONE, vol. 6, e27558. DOI: 10.1371/journal. pone. 0027558 .

BERG, G. - SMALLA, K. 2009. Plant species and soil type cooperatively shape the structure and function of microbial communities in the rhizosphere. In FEMS Microbiology Ecology, vol. 68, pp. 1-13. DOI: $10.1111 / \mathrm{j} .1574-6941.2009 .00654 . x$.

BLACKWOOD, C.B. - BUYER, J.S. 2004. Soil microbial communities associated with Bt and non-Bt corn in three soils. In Journal of Environmental Quality, vol. 33, pp. 832-836. DOI: $10.2134 /$ jeq2004.0832.

BLACKWOOD, C.B. - HUDLESTON, D. - ZAK, D.R. - BUYER, J.S. 2007. Interpreting ecological diversity indices applied to Terminal Restriction Fragment Length Polymorphism data: Insights from simulated microbial communities. In Applied and Environmental Microbiology, vol. 73, no. 16, pp. 5276-5283. DOI: 10.1128/AEM.00514-07.

BRUSETTI, L. - FRANCIA, P. - BERTOLINI, C. PAGLIUCA, A. - BORIN, S. - SORLINI, C. - ABRUZZESE, A. - SACCHI, G. - VITI, C. - GIOVANNETTI, L. - GIUNTINI, E. - BAZZICALUPO, M. - DAFFONCHIO, D. 2005. Bacterial communities associated with the rhizosphere of transgenic Bt176 maize (Zea mays) and its non transgenic counterpart. In Plant and Soil, vol. 266, no. 1, pp. 11-21. DOI: 10.1007/s11104-005-5399-x.

BUCKLEY, D.H. - SCHMIDT, T.M. 2001. The structure of microbial communities in soil and the lasting impact of cultivation. In Microbial Ecology, vol. 42, no. 1, pp. 11-21. DOI: 10.1007/s002480000108.

CLEGG, C.D. - LOVELL, R.D. - HOBBS, P.J. 2003. The impact of grassland management regime on the community structure of selected bacterial groups in soils. In FEMS Microbiology Ecology, vol. 43, pp. 263-270. DOI: 10.1111/j.1574-6941.2003.tb01066.x. COUPLAND, D. - CASELEY, J.C. 1979. Presence of ${ }^{14} \mathrm{C}$ activity in root exudates and guttation fluid from $\mathrm{Ag}$ ropyron repens treated with ${ }^{14} \mathrm{C}$-labeled glyphosate. In New Phytology, vol. 83, pp. 17-22.

DE-BASHAN, L.E. - HERNANDEZ, J.P. - BASHAN, Y. 2012. The potential contribution of plant growth-promoting bacteria to reduce environmental degrada- 
tion - A comprehensive evaluation. In Applied Soil Ecology, vol. 61, pp. 171-189. DOI: 10.1016/j.apsoil.2011.09.003.

DEVARE, M.H. - JONES, C.M. - THIES, J.E. 2004. Effect of Cry $3 \mathrm{Bb}$ transgenic corn and tefluthrin on the soil microbial community: biomass, activity, and diversity. In Journal of Environmental Quality, vol. 33, pp. 837-843. DOI: $10.2134 /$ jeq2004.0837.

DUNFIELD, K.E. - GERMIDA, J.J. 2001. Diversity of bacterial communities in the rhizosphere and root interior of field-grown genetically modified Brassica napus. In FEMS Microbiology Ecology, vol. 82, pp. 1-9. DOI: 10.1111/j.1574-6941.2001.tb00876.x

EDWARDS, U. - ROGALL, T. - BLÖCKER, H. - EMDE, M. - BÖTTGER, E.C. 1989. Isolation and direct complete nucleotide determination of entire genes: characterization of a gene coding for $16 \mathrm{~S}$ ribosomal RNA. In Nucleic Acids Research, vol. 17, pp. 7843-7853.

FANG, M. - MOTAVALLI, P.P. - KREMER, R.J. - NELSON, K.A. 2007. Assessing changes in soil microbial communities and carbon mineralization in Bt and non-Bt corn residue-amended soils. In Applied Soil Ecology, vol. 37, pp. 150-160. DOI: 10.1016/j.apsoil.2007.06.001.

GRIFFITHS, B.S. - GEOGHEGAN, I.E. - ROBERTSON, W.M. 2000. Testing genetically engineered potato, producing the lectins GNA and Con A, on non-target soil organisms and processes. In Journal of Applied Ecology, vol. 37, pp. 159-170. DOI: 10.1046/j.13652664.2000.00481.x.

GRIFFITHS, B.S. - CAUL, S. - THOMPSON, J. BIRCH, A.N.E. - SCRIMGEOUR, C. - CORTET, J. - FOGGO, A. - HACKETT, C.A. - KROGH, P.H. 2006. Soil microbial and faunal community responses to Bt maize and insecticide in two soils. In Journal of Environmental Quality, vol. 35, pp. 734-741. DOI: $10.2134 /$ jeq2005.0344.

GYAMFI, S. - PFEIFER, U. - STIERSCHNEIDER, M. - SESSITSCH, A. 2002. Effects of transgenic glufosinate-tolerant oilseed rape (Brassica napus) and the associated herbicide application on eubacterial and Pseudomonas communities in the rhizosphere. In FEMS Microbiology Ecology, vol. 41, pp. 181-190. DOI: $10.1111 / \mathrm{j} .1574-6941.2002 . t b 00979 . x$.

HEUER, H. - KROPPENSTEDT, R.M. - LOTTMANN, J. - BERG, G. - SMALlA, K. 2002. Effects of T4 lysozyme release from transgenic potato roots on bacterial rhizosphere communities are negligible relative to natural factors. In Applied and Environmental Microbiology, vol. 68, pp. 1325-1335. DOI: 10.1128/ AEM.68.3.1325-1335.2002.

HEUER, H. - SMALLA, K. 1999. Bacterial phyllosphere communities of Solanum tuberosum L. and T4-lysozyme-producing transgenic variants. In FEMS Microbiology Ecology, vol. 28, no. 4, pp. 357-371. DOI: 10.1016/S0168-6496(98)00121-4.

HOULDEN, A. - TIMMS-WILSON, T.M. - DAY, M.J. BAILEY, M.J. 2008. Influence of plant developmental stage on microbial community structure and activity in the rhizosphere of three field crops. In FEMS Microbiology Ecology, vol. 65, pp. 193-201. DOI:
10.1111/J.1574-6941.2008.00535.X

ICOZ, I. - STOTZKY, G. 2008. Cry3Bb1 protein from Bacillus thuringiensis in root exudates and biomass of transgenic corn does not persist in soil. In Transgenic Research, vol. 17, pp. 609-620. DOI: 10.1007/ s11248-007-9133-8.

JOST, L. 2006. Entropy and diversity. In Oikos, vol. 113 , no. 2 pp. 363-375. DOI: $10.1111 /$ j.2006.00301299.14714.x.

KOWALCHUK, G.A. - BRUINSMA, M. - VAN VEEN, J.A. 2003. Assessing responses of soil microorganisms to GM plants. In Trends in Ecology and Evolution, vol. 18, no. 8, pp. 403-410. DOI: 10.1016/ S0169-5347(03)00187-3.

LI, X. - RUI, J. - MAO, Y. - YANNARELL, A. - MACKIE, R. 2014. Dynamics of the bacterial community structure in the rhizosphere of a maize cultivar. In Soil Biology \& Biochemistry, vol. 68, pp. 392-401. DOI: $10.1016 /$ j.soilbio.2013.10.017.

LIU, W.T. - MARSH, T.L. - CHENG, H. - FORNEY, L.J. 1997. Characterization of microbial diversity by determining Terminal Restriction Fragment Length Polymorphisms of genes encoding 16S rRNA. In $A p$ plied Environmental Microbiology, vol. 63, 45164522.

LUKOW, T. - DUNFIELD, P.F. - LIESACK, W. 2000. Use of T-RFLP technique to assess spatial and temporal changes in the bacterial community structure within an agricultural soil planted with transgenic and non-transgenic potato plants. In FEMS Microbiology Ecology, vol. 32, pp. 241-247. DOI: 10.1111/j.15746941.2000.tb00717.x.

LUPWAYI, N.Z. - BLACKSHAW, R.E. 2013. Soil microbial properties in $\mathrm{Bt}$ (Bacillus thuringiensis) corn cropping systems. In Applied Soil Ecology, vol. 63, pp. 127-133. DOI: 10.1016/j.apsoil.2012.09.005.

MUYZER, G. - TESKE, A. - WIRSEN, C.O. - JANNASCH, H.W. 1995. Phylogenetic relationships of Thiomicrospira species and their identification in deep-sea hydrothermal vent samples by denaturing gradient gel electrophoresis of $16 \mathrm{~S}$ rDNA fragments. In Archives of Microbiology, vol. 164, no. 3, pp. 165172. DOI: $10.1007 / \mathrm{BF} 02529967$.

ONDREIČKOVÁ, K. - MIHÁLIK, D. - FICEK, A. HUDCOVICOVÁ, M. - KRAIC, J. -DRAHOVSKÁ, H. 2014. Impact of genetically modified maize on the genetic diversity of rhizosphere bacteria: A two-year study in Slovakia. In Polish Journal of Ecology, vol. 62, pp. 67-76. DOI: 10.3161/104.062.0107.

PIELOU, E.C. 1966. The measurement of diversity in different types of biological collections. In Journal of Theoretical Biology, vol. 13, pp. 131-144.

PRISCHL, M. - HACKL, E. - PASTAR, M. - PFEIFFER, S. - SESSITSCH, A. 2012. Genetically modified Bt maize lines containing cry3Bb1, crylA105 or cry$1 A b 2$ do not affect the structure and functioning of root-associated endophyte communities. In Applied Soil Ecology, vol. 54, pp. 39-48. DOI: 10.1016/j.apsoil.2011.12.005

SAXENA, D. - FLORES, S. - STOTZKY, G. 2002. Bt toxin is released in root exudates from 12 transgen- 
ic corn hybrids representing three transformation events. In Soil Biology and Biochemistry, vol. 34, pp. 133-137. DOI: 10.1016/S0038-0717(01)00161-4.

SHANNON, C.E. - WEAVER, W. 1948. A mathematical theory of communication. In The Bell System Technical Journal, vol. 2, pp. 379-423 and 623-656.

SONG, Y.A. - SU, J. - CHEN, R. - LIN, Y. - WANG, F. 2014. Diversity of microbial community in a paddy soil with crylAc/cpti transgenic rice. In Pedosphere, vol. 24 , no. 3, pp. 349-358. DOI: 10.1016/S10020160(14)60021-7.

VALVERDE, J.R. -MARÍN, S. - MELLADO, R.P. 2014. Effect of herbicide combinations on Bt-maize rhizobacterial diversity. In Journal of Microbial Biotechnology, vol. 24, no. 11, pp. 1473-1483. DOI: 10.4014/ jmb.1405.05054.

Received: January 12, 2016 